\title{
BOB ALTING VON GEUSAU \\ 1946-1999
}

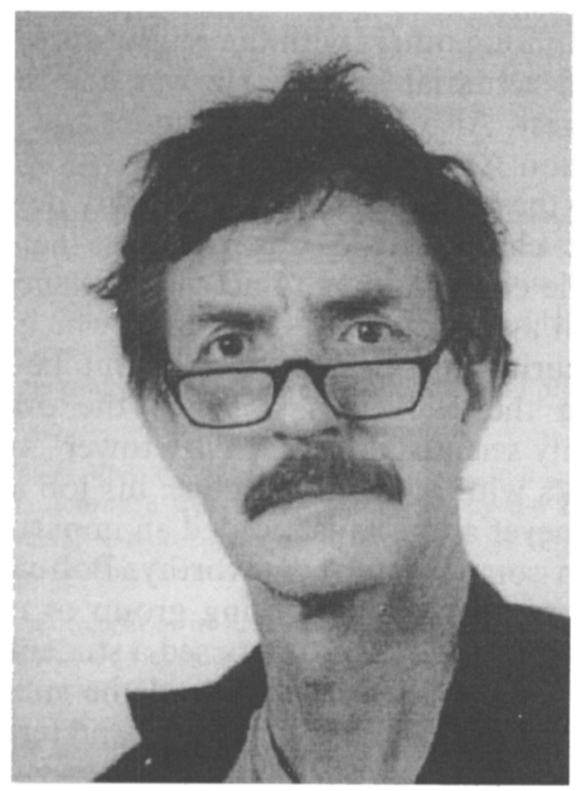

Bob Alting von Geusau died on November 4, 1999, only 53 years old. Though optimistic to the last, he knew he was terribly ill; with a final effort, he had given his goodbye lecture as a professor of actuarial science only a few weeks before. This impressive lecture, aptly called "The survival of the fittest", essentially described the plans he had had for the remainder of his career. It was attended by some 600 of his friends, colleagues and former students. It was a sad occasion, but endurable because of the way Bob handled his predicament, making everybody laugh at his stories and anecdotes.

By students and colleagues alike, he will be sorely missed at the actuarial department of the University of Amsterdam. Apart from being an excellent and inspiring teacher and a really pleasant colleague, he was also outstanding at promoting actuarial science in the Netherlands. $\mathrm{He}$ persuaded many students to choose our profession, by presenting them with exotic and inspiring tales at their schools while they were trying to select a career. A recurrent part of these sessions was "Around the world in 80 questions". A prospective student would be asked to name any country in the world, and Bob produced an interesting story about insurance relating to 
this particular country. For these, he could draw from his years of experience. He managed to make actuarial science sound so much more interesting than accountancy!

Bob has been involved with the department of actuarial science for a period of around 30 years. First as an assistent of the late Jaap van Klinken, then, after a period outside the university, as his successor. In the period between, he worked among others with the reinsurance company NRG, and later started his own actuarial bureau. He was a former chairman of the Dutch Actuarial Society. Also, he was the founder and for a long period the chairman of the section AFIR.

Apart from being the best PR-officer a university department could wish, his most important characteristic was perhaps that he was incredibly versatile: he has made contributions to actuarial science in life and in nonlife insurance, as well as of course in the field in which he was appointed a professor, social security and pension funds. But he was also a pioneer promoting AFIR in the Netherlands. While the other lecturers at the department are mainly scientists of the "ivory tower" type, Bob has always maintained close links with actuarial practice; his job at the university was only part-time. Whenever a journalist needed an impartial and well-founded academic opinion on some matter newsworthy, Bob was able to give one. Invariably, he had presided some working group or conference attending just this matter a few years ago, had supervised a student writing his master's thesis about the subject, or had simply found the subject interesting. The Dutch Actuarial Society asked him to serve a second term as its chairman, in the period they celebrated their 100th anniversary. He was a really outstanding public speaker, and great at organizing meetings where he could display this ability.

Astineers will fondly remember Bob from many ASTIN-colloquia, presenting a paper or being the chairman of a session. He was not only fluent in English and French, but also quite at home in Italian and some other languages. When he did give a talk in English, he pleased the part of the audience not quite so fluent in this language by using transparencies in French. One time, giving a talk on an application of compound Poisson distributions in Lausanne, in the few minutes allotted to him he meticulously explained to the audience the ins and outs of a traditional Dutch family game "sjoelbakken", a variant of shovel-board. In later years, his interests had shifted from ASTIN-subjects to the topics he was teaching, the Dutch system of social security and pension funds.

It will be hard to fill his position at our department. Our hearts go out to his wife Hedwig and their children Karen and Niels.

ROB KAAS 